\title{
Preliminary Data Regarding Pharmaceutical Forms Type Gels Based on Marine Algae Extracts with Antioxidant Activity
}

\author{
Ticuţa Negreanu-Pîrjol \\ 1 “Ovidius" University of Constanţa, Faculty of \\ Pharmacy, Constanţa, Romania \\ Bogdan-Ştefan Negreanu-Pîrjol \\ 1 "Ovidius" University of Constanţa, Faculty of \\ Pharmacy, Constanţa, Romania \\ Dan Razvan Popoviciu \\ "Ovidius" University of Constanța, Faculty of Natural \\ Sciences and Agricultural Sciences, Constanţa, Romania \\ Florentina Nicoleta Roncea \\ 1 "Ovidius" University of Constanţa, Faculty of \\ Pharmacy, Constanţa, Romania
}

\section{Abstract}

Particularly interest on herbs and plant extracts is due to their content of active principles with remarkable pharmacological properties. Different vegetal species contain natural antioxidants (polyphenols) used for their dermatological anti-inflammatory and healing activity, justified by their action on free radicals. The aim of this paper was to obtain selected phytopharmaceuticals formulations type gels with an increased antioxidant potential based on a mixture of fluid extracts from seaweeds species in the phylum Chlorophyta, Cladophora vagabunda (L.) C. Hoek, in the family Cladophoraceae, Ulva lactuca (L.) syn. Ulva rigida (L.), in the family Ulvaceae (sea lettuce) and species in the phylum Rhodophyta, Ceramium rubrum C. Agardh, in the famiy Ceramiaceae, frequently presents along the Romanian Black Sea coast. Fluid extracts concentration $10 \%$ were obtained using cold maceration extraction method, in solvents ethylic alcohol $40 \%$ and $70 \%$. The obtained vegetal extracts were mixed in different ratio and analysed for physico-chemical properties, for the content of total phenols, chlorophylls, cartenoids, flavonoids and antioxidative capacity by photochemiluminescence method (ACL, Analytik Jena AG procedure). The selected mixed fluid extracts with greatest content of polyphenols and antioxidant activity were used for obtaining pharmaceutical forms type gels 
which were analyzed for the physical-chemical properties appearance, $p \mathrm{H}$, spredability and total antioxidative capacity. Preliminary results emphasized that proposed pharmaceutical forms type gels had an appreciable antioxidant activity correlated with a good stability, an increased polyphenols content and would represent a possible new dermatological anti-inflammatory and healing preparation.

Keywords: pharmaceutical formulation, gels, marine algae, Black Sea littoral, total antioxidant capacity

\section{Introduction}

Seaweeds - are aquatic photosynthetic organisms used largely due to the variety of bioactive compounds in their composition that have begun to attract the attention of the food, pharmaceutical and cosmetic industries. Functional components extracted from algae biomass are widely used as food and health supplements with a variety of applications in food science and technology. The applications of algae in dermocosmetic products are increasing due to the fact that they have a high potential in various treatments for dermal diseases.

There is a growing concern for valorization marine phytobenthic bioresources in cosmetic therapy and treatments, by using new biotechnologies to obtain innovative pharmaceutical and dermo-cosmetic preparations, for biocompatible external use, based on soft fluid extracts or dried purified green algae containing natural bioactive compounds, with antibacterial, antifungal, antiproliferative, antioxidant activity, with maximum efficiency and minimal side effects, non-allergenic, regenerative and with skin protection effect against UV radiation (www.seaweed.ie/; www.irishseaweeds.com/sea-lettuce-ulva-lactuca; www.hawaii.edu/reefalgae/invasive_algae/chloro/cladophora_vagabunda.htm; www.algaebase.org/search/species/; Lindberg M., 2010; Mshigeni K.E., 1991; Drum R.; Leandro A., 2020; Noel Vinay, 2013; Kennedy J., 2020; Pooja S., 2014; Ajit Kandale, 2011)

Marine green algae species along Black Sea coast, in the phylum Chlorophyta, Cladophora vagabunda (L.) C. Hoek, in the family Cladophoraceae, Ulva lactuca (L.) syn. Ulva rigida (L.), in the family Ulvaceae (sea lettuce), respectively red algae species in the phylum Rhodophyta, Ceramium rubrum C. Agardh, in the famiy Ceramiaceae,

are used in traditional medicine most due to their content in polyphenolic acids with increased antioxidative capacity mainly useful in anti-inflammatory diseases (Negreanu-Pirjol, 2012; Sirbu R., 2019; Negreanu-Pirjol B., 2011; Negreanu-Pirjol B.S., 2015; Negreanu-Pirjol B.S., 2018; Sirbu R., 2014; Negreanu-Pirjol T., 2019).

The aim of this paper is the evaluation of the total phenols compounds, chlorophylls, cartenoids, flavonoids content in hydroalcoholic extracts of Cladophora vagabunda 
(L.) C. Hoek, Ulva lactuca (L.) syn. Ulva rigida (L.), and Ceramium rubrum C. Agardh species along Romanian Black Sea coast, knowing that these three vegetal products present an increased antioxidant activity with a real phytotherapeutic potential. The selected fluid extracts with increased content of polyphenols were used for hydrogels obtaining (Negreanu-Pirjol T., 2015; Sirbu R., 2010; Negreanu-Pirjol T., 2014; Negreanu-Pirjol T., 2014). The pharmaceutical formulations type gels had a good stability in time and the most increased total antioxidant capacity, better than the fluid vegetal extracts used as raw materials.

\section{Material and Methods}

Fresh vegetal product selected for fluid extracts obtaining represented by Cladophora vagabunda (L.) C. Hoek (Chlorophyta, Fam. Cladophoraceae), Ulva lactuca (L.) syn. Ulva rigida (L.) (Chlorophyta, Fam. Ulvaceae) and Ceramium rubrum C. Agardh (Rodophyta, Fam. Ceramiaceae) species, were manual collected from the South Romanian Coast of Black Sea, sector between Mangalia - 2 Mai - Vama Veche, the medio-littoral area, in the period June - August 2019-2020 and sorted on species (Fig. 1). The three species are commonly found on the Romanian Black Sea coast, growing on rocky substrates (AOAC, 2016).

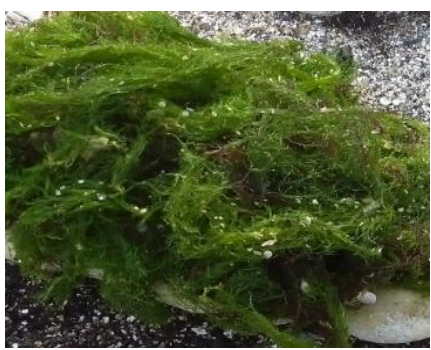

1.

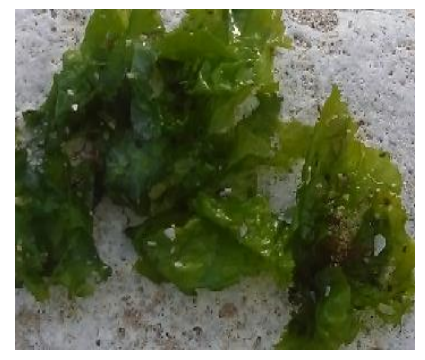

2.

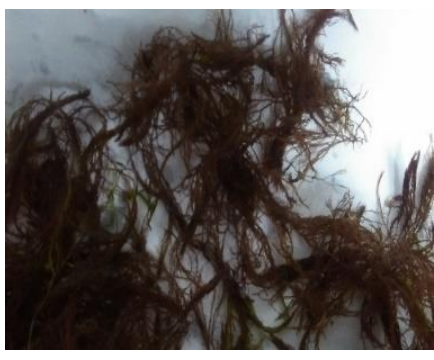

3.

Fig. 1. Fresh vegetal material - marine algae species along Black Sea Cost

(1. Cladophora vagabunda (L.) C. Hoek (Chlorophyta, Fam. Cladophoraceae); 2. Ulva lactuca (L.) syn. Ulva rigida (L.) (Chlorophyta, Fam. Ulvaceae); 3. Ceramium rubrum C. Agardh (Rodophyta, Fam. Ceramiaceae) (photo: Dragonea)

The immediately pretreatment process after harvesting involves washing the biomass thoroughly several times with distillated water, to remove adhering sand particles and impurities and dried at room temperature, for 24 hours, in the dark. Fresh marine algae biomass was weighed to determine the loss of water through drying process. The dried algae material from three species, Cladophora vagabunda, Ulva lactuca and Ceramium rubrum was macerated to a fine powder (homogeneous, as well as a higher surface-to-volume ratio) and investigated for chlorophyll pigment, carotenoids, total flavonoids and total phenolic content and total antioxidant capacity, with triplicate samples of each determination. 
For fluid extract obtaining - maceration method at cold of vegetal product was used: ethylic alcohol 40\% and 70\% 1:10 ratio, stir and allow soaking in the dark for 10 days in a constant temperature and stirred periodically. After 10 days, the extract is filtered and brought to a concentration of $10 \%$ with a $100 \mathrm{~mL}$ volumetric flask. After the 10 days obtained extract was filtered and stored at $4{ }^{\circ} \mathrm{C}$ (Negreanu-Pirjol B.S., 2015, Negreanu-Pirjol T., 2019). For the fluid extracts, $p \mathrm{H}$, relative density were determined.

Semisolid gels based on Cladophora - Ulva - Ceramium (C-U-C) fluid extracts quality control standard tests were the follows: appearance, homogeneity, $p \mathrm{H}$ and spreadability, initial and after 30 days of obtaining (Negreanu-Pirjol T., 2015, NegreanuPirjol T., 2014).

$p \mathrm{H}$ was achieved using a Consort electronic $p \mathrm{H}$-meter with temperature sensor

For relative density, the pycnometer method was used

For chlorophyll and carotenoid content, $0.1 \mathrm{~g}$ ground dry algal material was extracted in $10 \mathrm{~mL} 80 \%$ acetone (triplicate samples for each species), $1 \%$ final, through UV-Vis spectrophotometric analysis (using a S106 WPA spectrophotometer) at 470, 647 and $663 \mathrm{~nm}$ wavelenghts. The concentrations of chlorophyll $a$, chlorophyll $b$ (only in chlorophytes) and total xanthophyll and carotin were calculated by using the trichromatic equations (Lichtenthaler \& Buschmann, 2001, Miazek K., 2011)

For total flavonoid determinations, 1 g ground vegetal tissue was extracted in $5 \mathrm{~mL}$ methanol and filtered (triplicate samples). $0.5 \mathrm{~mL}$ of extract was diluted in $4 \mathrm{~mL}$ water and $8 \mathrm{~mL}$ methanol mixture, and the spectrophotometric absorbance was read against a methanol blank at $340 \mathrm{~nm}$ wavelength (Szabo I., 2012).

For determining the concentration of total phenolic compounds, a spectrophotometric version of the Folin-Ciocâlteu method was used. $0.1 \mathrm{~g}$ fruit tissue was extracted in 10 $\mathrm{mL}$ methanol and filtered. $1 \mathrm{~mL}$ of extract was reacted with $5 \mathrm{~mL}$ Folin-Ciocâlteu reagent (10\%) and $4 \mathrm{~mL}$ sodium bicarbonate solution $(7.5 \%)$ for 30 minutes. Spectrophotometric absorbance was read against a blank at $765 \mathrm{~nm}$. A calibration curve was prepared, by using different gallic acid concentrations [10-12]. The resulting concentration was expressed as $\mathrm{mg} / \mathrm{kg}$ dry weight and $\mathrm{mg} / \mathrm{kg}$ DW gallic acid equivalent (GAE), (Stanković M.S., 2011; Stanković , 2011; Siddiqui N., 2017).

Semisolid gels preparation based on Cladophora - Ulva - Ceramium (C-U-C) seaweeds species fluid extracts was as follows (Tables 1, 2) (Popovici I., 2011):

\section{Table 1. Samples Codification}

\begin{tabular}{ll}
\hline $\begin{array}{l}\text { Seaweeds C-U-C fluid extracts } \\
\text { concentration } 10 \%\end{array}$ & Gels \\
\hline Maceration in $40 \%$ alcohol $(1: 1: 1)$ ratio & G1 \\
\hline Maceration in $70 \%$ alcohol, $1: 1: 1)$ ratio & G2 \\
\hline Maceration in $40 \%$ alcohol, $(1: 2: 2)$ ratio & G3 \\
\hline Maceration in $70 \%$ alcohol, $(1: 2: 2)$ ratio & G4 \\
\hline
\end{tabular}


Table 2. Carbopol gel $1 \%$ formula based on $C-U-C$ fluid extracts (G1 -G4)

\begin{tabular}{lll}
\hline Ingredients & $\begin{array}{l}\text { Quantities (g) } \\
\mathrm{G} 1-\mathrm{G} 2\end{array}$ & $\begin{array}{l}\text { Quantities (g) } \\
\mathrm{G} 3-\mathrm{G} 4\end{array}$ \\
\hline Carbopol 940 & 1 & 1 \\
\hline Triethanolamine & 0.8 & 0.8 \\
\hline Propylenglicole & 5 & 5 \\
\hline C-U-C fluid extracts (1:1:1) ratio & 7.5 & - \\
\hline C-U-C fluid extracts (1:2:2) ratio & - & 7.5 \\
\hline Preservative solution ad & 100 & 100
\end{tabular}

Carbopol 940 1\% gel based on C-U-C fluid extracts obtaining: disperse carbopol 940 in the preservative solution, shake vigorously (with a high speed electric stirrer) to avoid the formation of agglomerates The dispersion was neutralized gradually with triethanolamine solution so as not to include air. Fill with preservative solution to 100 $\mathrm{g}$ add and mixed the fluid extracts.

\section{Total Antioxidant Capacity (TEAC) by photochemiluminescence method}

Apparatus: photochemiluminometer PHOTOCHEM, Analytik Jena AG, Germany

Samples preparation:

Stock solutions for seaweeds C-U-C fluids extracts, were prepared as follows: $10 \mathrm{~g}$ powder mixture of seaweeds (molar ratio C-U-C 1:1:1, respectivelly molar ratio 1:2:2) were diluted with $100 \mathrm{~mL}$ ethyl alcohol concentration 40\%, respectivelly $70 \%$. From the stock solutions, were taken $10 \mu \mathrm{L}$ working volume, according with Antioxidative Capacity in Lipid-soluble substances (ACL) (Hermann H., 2004).

Stock solution for semisolid pharmaceutical forms type gels, were prepared as folloys: $5 \mathrm{~g}$ of C-U-C gels were diluted with $5 \mathrm{~mL}$ ethyl alcohol 95\%. From the stock solutions, were taken $10 \mu \mathrm{L}$ working volume, according with Antioxidative Capacity in Lipidsoluble substances (ACL) (procedure, Analytik Jena AG, 2004).

The total antioxidant capacity of the samples were quantified by comparison with the standard Trolox (constructing a calibration curve with Trolox®) (Fig. 2) and were quantified as equivalent units of standard substance Trolox equivalent antioxidant activity (TEAC) is a measurement of antioxidant strength based on Trolox, (6hydroxy-2,5,7,8-tetramethylchroman-2-carboxylic acid), a water-soluble derivative of vitamin E, in units called Trolox Equivalents (TE). Due to the difficulties in measuring individual antioxidant components of a complex mixture, Trolox equivalency is used as a benchmark for the antioxidant capacity of such a mixture, nmol/sample (Shahidi F., 1999; Popovov I., 1999; Le Tutour B., 1990; Döll M., 2003; Winnefeld K., 1995). 
From stock solutions were prepared the samples, as follow (Table 3):

Table 3. Working scheme (volumes in $\boldsymbol{\mu L}$ ), (Hermann $\mathrm{H}, 2004$ )

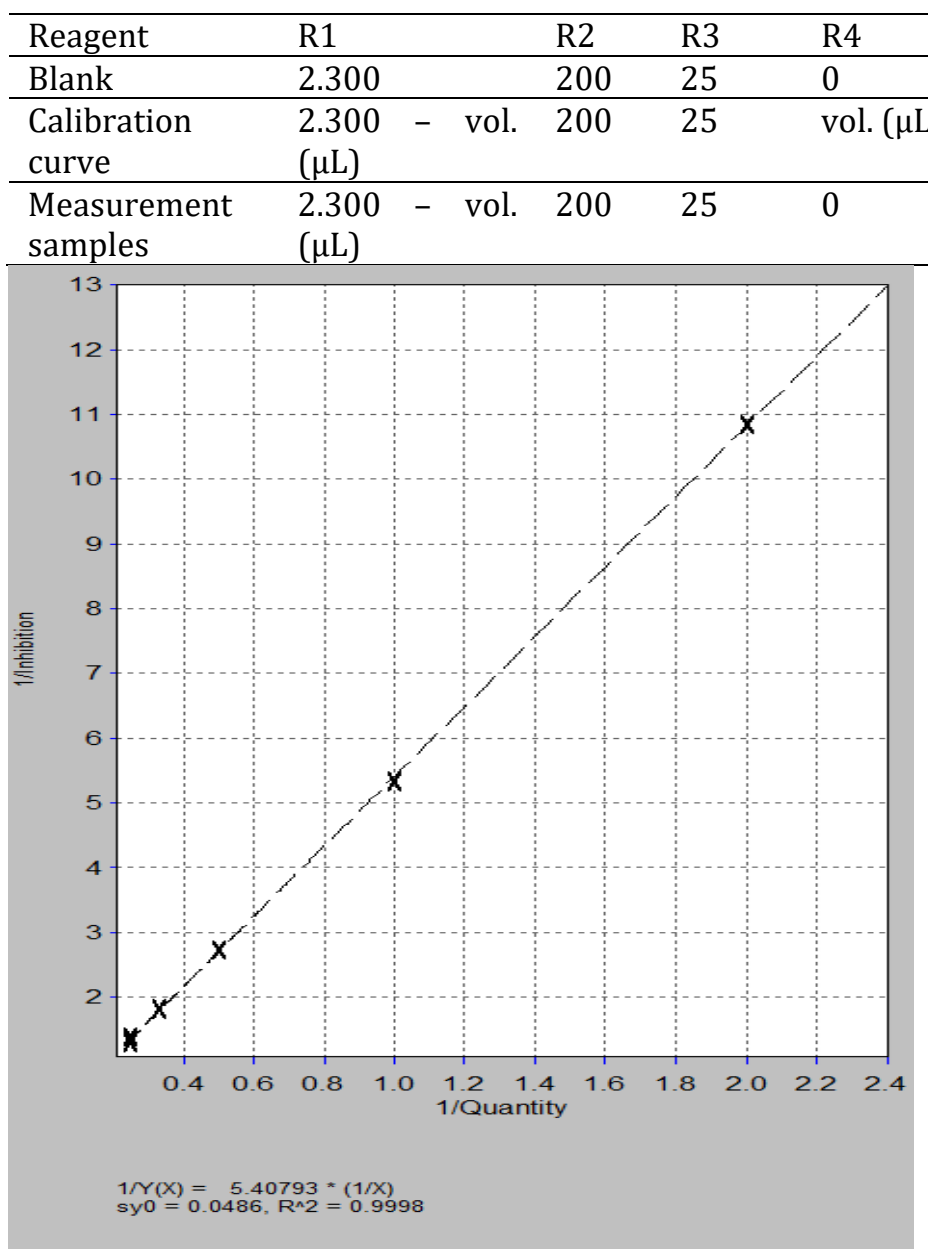

Fig. nr. 2. Trolox standard calibration curve (ACL method, Analytik Jena AG) Results and Discussions

The values of the $p \mathrm{H}$ and relative density parameters did not significantly modified, proving a good compatibility between the selected bases and C-U-C seaweeds fluid extracts (Table. 3 ).

Table 3. Seaweeds C-U-C fluid extracts quality control results

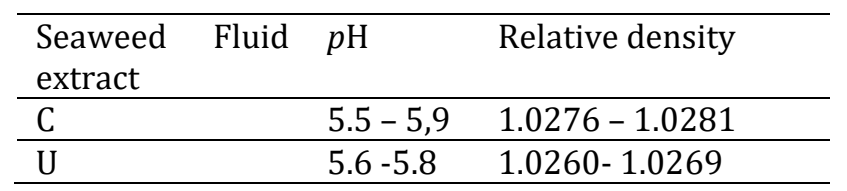


- Macroalgae fluid extracts chlorophylls pigments content determination

- Chlorophylls pigments contents of green algae fluid extracts at 10\% concentration of algal extracts, emphasize an increased values for both species, as follows: Chlorophyll $a$ concentration was the highest in Cladophora $(488,427 \mathrm{mg} / \mathrm{kg})$, while maximum chlorophyll $b$ content was found in Ulva lactuca $(321,700 \mathrm{mg} / \mathrm{kg})$, Fig. 3.

- The chlorophyll a content was highest in the case of Ulva lactuca, $(918,988$ $\mathrm{mg} / \mathrm{kg}$ ), than Cladophora vagabunda (488,427 mg.kg) and Ceramium rubrum $(119,597 \mathrm{mg} / \mathrm{kg})$, Fig. 3.

- Macroalgae fluid extracts carotenoids pigments content determination

- High carotenoid concentrations were found in Cladophora vagabunda (196 $\mathrm{mg} / \mathrm{kg}$ ) and Ceraminum rubrum $(90 \mathrm{mg} / \mathrm{kg})$, compared with a decreased content registered for Ulva lactuca (11,366 mg/kg), Fig. 4

- Macroalgae fluid extracts flavonoids content determination

- Dry Cladophora vagabunda tissue contain the highest amount of flavonoids $(2,707 \mathrm{mg} / \mathrm{kg})$, compared with a decreased content of Ulva lactuca $(44,590$ $\mathrm{mg} / \mathrm{kg})$ and Ceramium rubrum $(19,110 \mathrm{mg} / \mathrm{kg})$, Fig. 5 .

- Macroalgae fluid extracts total phenols content determination

- Total phenols content was less variable, with the highest value in Cladophora tissue $(5,888 \mathrm{mg} / \mathrm{kg} \mathrm{GAE})$ and a decreased values for Ceramium rubrum $(4,201 \mathrm{mg} / \mathrm{kg})$ and Ulva lactuca $(3,780 \mathrm{mg} / \mathrm{kg})$, Fig. 6 .

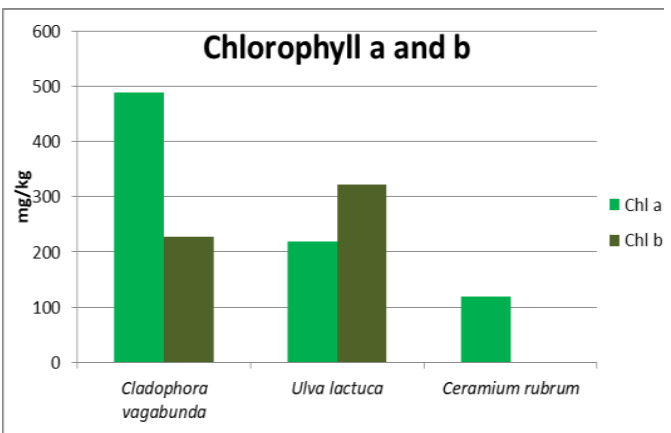

Fig. 3. Chlorophyll content in dry algal tissue $(\mathrm{mg} / \mathrm{kg})$

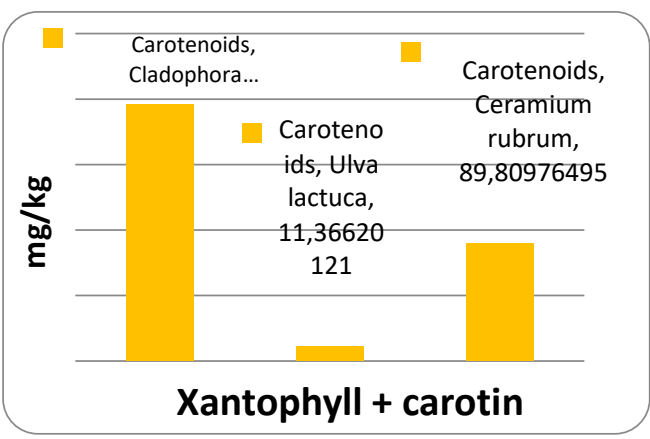

Fig. 4. Total carotenoid content in dry algal tissue $(\mathrm{mg} / \mathrm{kg})$ 


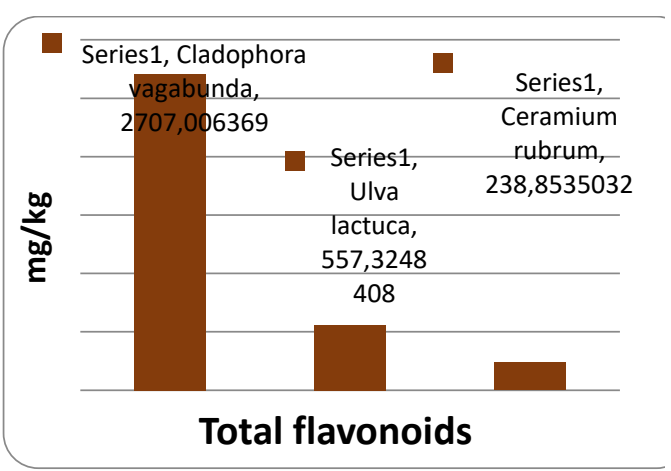

Fig. 5. Total flavonoid content in dry algal tissue $(\mathrm{mg} / \mathrm{kg})$

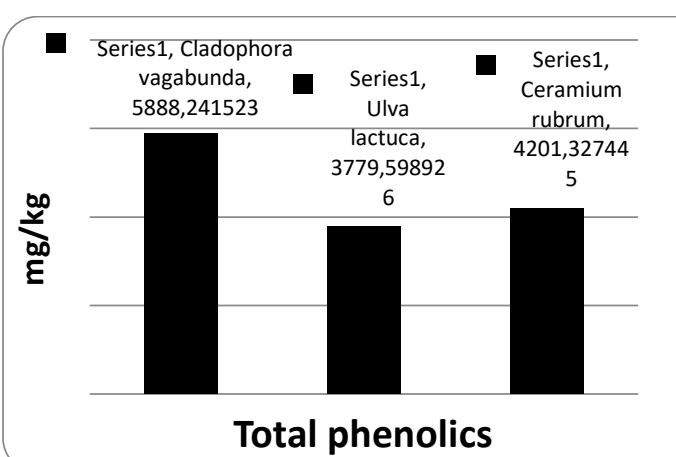

Fig. 6. Total phenolic content in dry algal tissue $(\mathrm{mg} / \mathrm{kg})$

The values of the determined physical-chemical parameters did not significantly modified, proving a good compatibility between the selected pharmaceutical bases and seaweeds C-U-C fluid extracts (Table 4).

Table 4. Physical-chemical parameters for semisolid pharmaceutical preparations type gels based on

\section{C-U-C seaweeds fluid extracts}

\begin{tabular}{ll}
\hline Parameter & $\begin{array}{l}\text { Gels based on UCT fluid extracts } \\
(\mathrm{G} 1-\mathrm{G} 4)\end{array}$ \\
\hline appearance & $\begin{array}{l}\text { translucent mass, yellow - greenish color, sweet taste, } \\
\text { characteristic smell }\end{array}$ \\
\hline homogeneity & $\begin{array}{l}\text { homogenous aspect without air bubbles, drops or } \\
\text { particle clusters }\end{array}$ \\
\hline$p \mathrm{H}$ & $5.6-6.5$ \\
\hline spreadability $(\mathrm{cm})$ & $10.56-32.448$ \\
\hline
\end{tabular}

Total antioxidant capacity (TEAC) for seaweeds C-U-C fluid extracts, respectivelly for gels G1 - G4 based on seaweeds C-U-C fluids extracts in presented in Table 5.

Table 5. Total antioxidant capacity (TEAC) of seaweeds C-U-C fluids extracts and gels based on seaweeds C-U-C fluid extracts

\begin{tabular}{lllll}
\hline N & $\begin{array}{l}\text { Sample type } \\
\text { (stock solution) }\end{array}$ & $\begin{array}{l}\text { Volum } \\
\text { e } \\
\text { sample } \\
(\mu \mathrm{L})\end{array}$ & $\begin{array}{l}\text { Inhibition } \\
\text { value }\end{array}$ & $\begin{array}{l}\text { Quantity mean } \\
\text { (TEAC) } \\
\text { (nmol equiv. Trolox/ } \\
\text { volume sample) }\end{array}$ \\
\hline 1 & $\begin{array}{l}\text { Seaweeds C-U-C fluid } \\
\text { extracts }(1: 1: 1) \text { ratio in } \\
\text { ethyl alcohol 40\% }\end{array}$ & 0.280 & 1.112 \\
\hline 2 & $\begin{array}{l}\text { Seaweeds C-U-C fluid } \\
\text { extracts (1:1:1) ratio in }\end{array}$ & 0.410 & 3.526 \\
\hline
\end{tabular}




\begin{tabular}{lllll}
\hline \multicolumn{3}{l}{ ethyl alcohol 70\% } & & \\
\hline 3 & $\begin{array}{l}\text { Seaweeds C-U-C fluid } \\
\text { extracts }(1: 2: 2) \text { ratio in } \\
\text { ethyl alcohol 40\% }\end{array}$ & & & \\
\hline $\begin{array}{l}\text { C-U-C fluid extracts } \\
(1: 2: 2) \text { ratio in ethyl } \\
\text { alcohol 70\% }\end{array}$ & & 0.387 & 3.702 \\
\hline 4 & Gel 1 & 10 & 0.123 & \\
\hline 5 & Gel 2 & 10 & 0.224 & 1.127 \\
\hline 6 & Gel 3 & 10 & 0.359 & 2.341 \\
\hline 7 & Gel 4 & 10 & 0.389 & 2.991 \\
\hline
\end{tabular}

The results obtained for total antioxidat capacity (TEAC) determinations, emphasize the follows:

at the working solution volume $(10 \mu \mathrm{L})$ according to the procedure, it was observed a valuable TEAC for all the analyzed semisolid pharmaceuticals preparations type gels (G1 - G4), between 1.127 - $2.991 \mathrm{nmol}$ equiv. Trolox / volume sample, but more decreased compare with the raw material - seaweeds C-U-C fluid extracts. The most increased total antioxidant capacity value for sample Gel 4 (2.991 nmol equiv. Trolox / volume sample), was registered.

at the working solution volume $(10 \mu \mathrm{L})$ according to the procedure, it was observed an increased TEAC for seaweeds C-U-C fluid extracts samples, with values between 1.112 - 3.702 nmol equiv. Trolox / volume, more increased compare with the registered values of gels (G1 - G4) obtained from the same seaweeds C-U-C fluids extracts. The most increased total antioxidant capacity value for sample C-U-C fluid extract (1:2:2) ratio in ethyl alcohol 70\% (3.702 nmol equiv. Trolox / volume sample), was registered.

\section{Conclusions}

Gels based on C-U-C seaweeds fluid extracts did not have modifications in quality parameters change during 30 days of observation,

Total antioxidant capacity was highest for semisolid pharmaceuticals preparations Gel 4 and seaweeds C-U-C fluids extracts used for obtaining G4 were extracted under maceration with alcohol 70\%, mixed in 1:2:2 ratio.

Method of extraction, nature of used vegetable products, fluid extracts ratio determined good values for total antioxidant capacity, in this case, nature of the pharmaceutical base used for gels obtaining, did not interfere with total antioxidant capacity, which was increased for semisolid pharmaceuticals preparations Gel 4 .

The obtained semisolid preparations G4 could be further submitted to other tests for its antioxidant properties valorification. 
Pharmaceutical formulations type gels based on marine algae, had an increased total antioxidant capacity correlated with a good stability and increased polyphenols content and would represent a possible new dermatological anti-inflammatory and healing preparations with antioxidant potential against free radicals action.

\section{Acknowledgements}

The authors would like to express appreciation for the financial support of the Romanian Ministry of Research - UEFISCDI, for Complex Project no. 85PCCDI / 2018, Acronym INOBIOMAR, Project code PN-III-P1-1.2-PCCDI-2017-0701.

\section{References}

[1] AOAC, Official methods of analysis, (2016) Official Methods of Analysis of AOAC International 20th Edition method 978.04

[2] Ajit Kandale, Meena A K, Rao M M, Panda P, Mangal AK, Reddy G, Ramesh Babu, Marine algae: An Introduction, Food value and Medicinal uses, Journal of Pharmacy Research 2011, 4(1),219-221

[3] Döll, Michaela, Das Antioxidantienwunder, Herbig, 2003

[4] Drum R., Island Herbs, Medicinal uses of sea weeds, http://ryandrum.com/seaweeds.html)

[5] https://www.centralcoastbiodiversity.org/sea-hair-bull-ulvaintestinalis.html

[6] http://www.seaweed.ie/

[7] www.irishseaweeds.com/sea-lettuce-ulva-lactuca

[8] Hermann H., Quantitation of Antioxidants by Photo-induced Chemiluminescence. Analytik Jena AG, Procedure for the determination of the antioxidative capacity of lipid-soluble substances with the Photochem, 2004, unpublished data

[9] https://www.hawaii.edu/reefalgae/invasive_algae/chloro/cladophora_vaga bunda.htm

[10] http://www.algaebase.org/search/species/

[11] Kennedy J., What Are the Uses for Seaweeds?, ThoughtCo, Aug. 28, 2020, https://www.thoughtco.com/human-uses-for-seaweeds-2291917

[12] Leandro A., Pereira L., Gonçalves A.M.M., Diverse Applications of Marine Macroalgae, Mar. Drugs, 2020, 18, 17; 1-15,

doi:10.3390/md18010017www.mdpi.com/journal/marinedrugs

[13] Le Tutour, B., Antioxidative activities of algae extracts, synergic effects with vitamina E, Phytochem., 1990, 29(12), 3759-3765

[14] Lichtenthaler H.K., Buschmann C., Chlorophylls and carotenoids:

Measurement and characterization by UV-VIS spectroscopy, in R.E. Wrolstad (ed.), Current Protocols in Food Analytical Chemistry, John Wiley \& Sons Inc., Hoboken, 2001, F4.3: 1-8.

[15] Lindberg M., Linstrom S., Ulva intestinalis. Seaweeds of Alaska, 2010, 
[16] Miazek K., Chlorophyll extraction from harvested plant material, in ČVUT Praha, Fakulta Strojní, Chemické potravinářské strojnictví, Procesní technika, 2011, http://chps.fsid.cvut. cz/pt/2011/pdf/1100011-1.pdf.

[17] Mshigeni K.E., Seaweeds in medicine and pharmacy: A global perspective, in Traditional Medicinal Plants, Dar Es Salaam University Press, Ministry of Health, Tanzania, 1991, 391 p., Part I

[18] Negreanu-Pîrjol T., Negreanu-Pîrjol B., Sîrbu R., Paraschiv G., Meghea A., Comparative studies regarding the antioxidative activity of some therapeutic marine algae species along Romanian Black Sea Coast, J Environ Prot Ecol, vol. 13, No. 3A, (2012), 1744-1750

[19] Negreanu-Pîrjol B., Negreanu-Pîrjol T., Paraschiv G., Bratu M., Sîrbu R., Roncea F., Meghea A., Physical-chemical characterization of some green and red macrophyte algae from Romanian Black Sea littoral, Scientific Study \& Research-Chemistry \& Chemical Engineering, Biotechnology, Food industry, 2011, 12 (2), $173-184$

[20] Negreanu-Pîrjol B.-Ş., Negreanu-Pîrjol T., Paraschiv G.M., Lepadatu A.C., H. Miresan, Antioxidative activity of some macrophyte algae extracts from South Romanian Black Sea Coast, $15^{\text {th }}$ International Multidisciplinary Scientific GeoConferences - SGEM 2015 - Nano, Bio and Green - Technologies for a Sustainable Future", 18 - 24 June 2015, Albena, Bulgaria, Conference Proceedings, Vol. I, Section Micro and Nano technologies, Advances in Biotechnology, 275 - 282

[21] Negreanu-Pirjol B.-S., Negreanu-Pirjol T., Mirea M., Vasile M., Cadar E., Antioxidant capacity of some marine green macroalgae species fluid extracts, $18^{\text {th }}$ International Multidisciplinary Scientific Conferences on Earth \& GeoSciences - SGEM Vienna Green 2018, 3 - 6 December 2018, Hofburg Congress Center, Vienna, Austria, Conference Proceedings, - Nano, Bio, Green and Space Technologies for a Sustainable Future, Vol. 18, Iss. 6.4, Section 8 Advances in Biotechnology, paper 51, 63 - 69

[22] Negreanu-Pirjol T., Sirbu R., Mirea M., Negreanu-Pirjol B.-S., Antioxidant activity correlated with chlorophyll pigments and magnesium content of some green seaweeds, European Journal of Medicine and Natural Sciences, Vol. 3, No. 1 (2019), January - April 2019

[23] Negreanu-Pirjol T., Roncea F., Popescu A., Miresan H., Negreanu-Pirjol B.-S., Pharmaceutical formulations based on indigene medicinal plant extracts with antioxidant activity, $15^{\text {th }}$ International Multidisciplinary Scientific GeoConferences-SGEM 2015-Nano, Bio and Green - Technologies for Sustainable Future", 18 - 24 June 2015, Albena, Bulgaria, Conference Proceedings, Vol. I, Section Micro and Nano technologies, Advances in Biotechnology, 499 - 506

[24] Negreanu-Pîrjol T., Roncea F, Negreanu-Pîrjol B.S., Sanda J., Sîrbu R., Moldovan L., Mireşan H., Correlation between in vitro cytotoxicity and antioxidant activity of some new bioadhesive gels based on chlorhexidine 
metallic complexes, $14^{\text {th }}$ International Multidisciplinary Scientific

GeoConferences „Surveying Geology \& mining Ecology Management - SGEM 2014", 17 - 26 June 2014, Albena, Bulgaria, Conference Proceedings, Section Advances in Biotechnology, Vol. I, 329 - 336

[25] Negreanu-Pîrjol T., Negreanu-Pîrjol B.S., Roncea F., Sanda J., Sîrbu R., Lepădatu A.C., Mireşan H., Semisolid pharmaceutical preparations based on metallic complex compounds of chlorhexidine salts with antimicrobial activity, $14^{\text {th }}$ International Multidisciplinary Scientific GeoConferences „Surveying Geology \& mining Ecology Management - SGEM 2014”, 17 - 26 June 2014, Albena, Bulgaria, Conference Proceedings, Section Advances in Biotechnology, Vol. I, 487 - 494

[26] Noel Vinay T., Se-Kwon K., Beneficial Effectsof Marine Algal Compounds in Cosmeceuticals, Mar. Drugs, 2013, 11, 146-164; doi:10.3390/md11010146

[27] Pooja S., Algae used as Medicine and Food-A Short Review, J. Pharm. Sci. \& Res. Vol. 6(1), 2014, 33 - 35

[28] Popov, I., Lewin, G., Antioxidative Homeostasis: Characterization by Means of Chemiluminescent Technique, Methods in Enzymology, Oxidants and Antioxidants, Part B, Ed. Lester Packer, Academic Press, New York, 300, 437, 1999

[29] Popovici, I., Lupuleasa, D., Tehnologie farmaceutică, vol. II, Ediţia a III-a, Editura Polirom, București, 2011.

[30] Shahidi, F., Ho, C.T., Phytochemicals and Phytopharmaceuticals, AOCS Press, Champaign, USA, 153, 1999

[31] Siddiqui N., Rauf A., Latif A., Mahmood Z., Spectrophotometric determination of the total phenolic content, spectral and fluorescence study of the herbal Unani drug Gul-e-Zoofa (Nepeta bracteata Benth), in J. Taibah Univ. Med. Sci., vol. 12, no. 4, 2017, pp. 360-363.

[32] Sirbu R., Negreanu-Pirjol T., Mirea M., Negreanu-Pirjol B.-S., Bioactive Compounds from Three Green Algae Species along Romanian Black Sea Coast with Therapeutically Properties, European Journal of Medicine and Natural Sciences, Vol. 3, No. 1 (2019), 5 -15

[33] Sîrbu R., Zaharia T., Maximov V., Bechir A.M., Mariş M., Negreanu-Pîrjol B., Mariş D., Negreanu-Pîrjol T., Leca M., Cadar E.M., Stoicescu R.M., Mocanu L., Jurja S., Clean bio-technologies for obtaining new pharmaceutical formulations based on collagen gels and marine algae extracts for medical applications, J Environ Prot Ecol, 2010, vol. 11, No. (2), 654 - 665

[34] Stanković M.S., Total phenolic content, flavonoid concentration and antioxidant activity of Marrubium peregrinum L. extracts, Kragujevac J. Sci., vol. 33, 2011, pp. 63-72.

[35] Stanković M.S., Niciforović N., Topuzović M., Slavica S., Total phenolic content, flavonoid concentrations and antioxidant activity, of the whole plant and plant parts extracts from Teucrium montanum L. var. montanum, f. 
supinum (L.) Reichenb., Biotechnol. \& Biotechnol. Eq., vol. 25, 2011, DOI: 10.5504/bbeq.2011.0020.

[36] Szabo I., Vonhaz G., Fodor A., Bungău S., Țiț D.M., The quantitative analysis through spectrophotometry of flavonoids and polyphenols from vegetable products Hibisci trioni herba, radix and fructus, Analele Universităţii din Oradea, Fascicula Protecția Mediului, vol. 18, 2012, pp. 73-80.

[37] Winnefeld, K., Sperschneider, H., Thiele, R., Peiker, G., Klinger, G., Antioxidantienstatus, Analytik und klinische Bedeutung; GIT Labor-Medizin 18, 355-357, 1995 